\title{
INTERSUBJECT VARIABILITY OF THALAMIC ACTIVATION DURING GENERATION OF BERGER'S ALPHA RHYTHM
}

\author{
Mateusz Rusiniak, Monika Lewandowska, Agnieszka Pluta, Katarzyna Ciesla, \\ Joanna Wojcik, Tomasz Wolak
}

Bioimaging Research Center, World Hearing Center of the Institute of Physiology and Pathology of Hearing, Warsaw/Kajetany, Poland

Corresponding author: Mateusz Rusiniak, World Hearing Center, Mokra 17 Street, Kajetany 05-830 Nadarzyn, Poland, e-mail:m.rusiniak@ifps.org.pl

\begin{abstract}
Background: The aim of the present work is to investigate the relationship between spontaneous electroencephalographic (EEG) brain activity at 8-13 Hz frequency (Berger's rhythm) and thalamus activation. The leading theory of how Berger's rhythm is generated suggests a thalamo-occipital circuit, but there is still much uncertainty as to the role of the thalamus.

Material and methods: We used a Siemens Magnetom 3T Trio scanner and a 64-channel NeuroScan SynAmps2 EEG system to examine 36 healthy young male adults. The study paradigm consisted of 30-s blocks with eyes closed alternated with 30-s blocks with eyes open, both repeated six times. The EEG data was preprocessed as follows: 1) fMRI gradient artifact removal; 2) BCG reduction; 3) 1-20 Hz band-pass filtration. Alpha rhythm segments were marked in the preprocessed data. fMRI data was preprocessed using typical procedures (motion correction, normalization, smoothing), and then a general linear model (GLM) analysis was performed using alpha segments derived from the EEG as events. A modified hemodynamic response function suitable for examining thalamus physiology was applied.
\end{abstract}

Results: EEG data produced a typical spatial distribution of the alpha rhythm, mostly elicited in the parieto-occipital electrodes. Group-level analysis of the fMRI data failed to reveal any activation in the thalamus. However, further investigation revealed three subgroups of patients: 1 ) those who had a signal decrease in the left medial dorsal nucleus; 2) those with positive activation of thalamic structures; and 3) those where no activation was detected in the thalamus.

Conclusions: The thalamus might be involved differently in alpha rhythm generation from one subject to another. The observed intersubject variability might be caused by physiological mechanisms underlying Berger's rhythm.

Keywords: alpha rhythm • EEG $\bullet \mathrm{fMRI} \bullet$ thalamus $\bullet$ simultaneous EEG-fMRI

\section{COMPROBACIÓN DE VARIACIÓN INTERINDIVIDUAL DE LA ACTIVIDAD DE TÁLAMO DURANTE LA GENERACIÓN DEL RITMO DE BERGER (RITMO ALFA)}

\section{Resumen}

Introducción: El objetivo del presente estudio ha sido examinar la asociación entre la actividad eléctrica espontánea del cerebro, visualizada a través de la técnica EEG para la frecuencia de $8-13 \mathrm{~Hz}$ (el llamado ritmo de Berger), y la activación del tálamo. La teoría más popular referente a la generación del ritmo de Berger sugiere su origen en la región del lazo tálamo - y el lóbulo occipital, pero en la literatura hay grandes discrepancias en cuanto al papel del tálamo en este proceso.

Materiales y métodos: Para las pruebas se ha utilizado el escáner Siemens Magnetom Trio del campo de inducción 3T y el sistema de 64 canales SynAMps 2 de la marca Neuroscan. En el estudio participaron 36 hombres jóvenes sanos. El régimen de pruebas consistió en bloques alternos, cuando la persona puesta a la prueba tuvo que tener los ojos cerrados o abiertos (un total de 12 bloques). El procesamiento de datos de EEG comprendía los siguientes pasos: 1) eliminación del artefacto causado por la acción de las bobinas de gradiente a consecuencia de la prueba fMRI, 2) reducción de artefacto BCG, 3) filtración paso banda para las frecuencias de $1 \mathrm{a} 20 \mathrm{~Hz}$. Los segmentos que abarcaban el ritmo alfa han sido marcados en los datos tras la filtración. Los datos fMRI han sido procesados de acuerdo con el procedimiento generalmente aceptado (corrección de movimiento, normalización y suavizado). El análisis con la aplicación del modelo lineal general (en inglés: general linear model GLM) ha sido realizado en base a los segmentos del ritmo alfa obtenidos del registro de EEG. Al modelar se utilizó la función de respuesta hemodinámica ajustada a la fisiología del tálamo.

Resultados: En base a los datos EEG se ha obtenido una distribución espacial del ritmo alfa típica, con la amplitud más alta observada en los electrodos en el lóbulo parietal y occipital. El análisis en grupo de los datos de fMRI no ha mostrado ninguna actividad relevante en la zona del tálamo. Sin embargo, una verificación en detalle de los datos ha permitido identificar 
tres subgrupos: 1) con la señal reducida en el núcleo ventromedial en el lado izquierdo 2) con una señal de mayor intensidad en la zona de cada una de las estructuras del tálamo 3) sin cambios visibles de la señal en el tálamo.

Conclusiones: En base a los resultados obtenidos, se puede observar que el tálamo puede ser involucrado de varias maneras en la generación del ritmo alfa. La variación interindividual puede ser provocada por los mecanismos fisiológicos relacionados con el ritmo de Berger.

\section{ВЕРИФИКАЦИЯ МЕЖ-ИНДИВИДУАЛЬНОЙ ВАРИАБЕЛЬНОСТИ АКТИВНОСТИ ТАЛАМУСА ВО ВРЕМЯ ГЕНЕРАЦИИ РИТМА БЕРГЕРА (АЛЬФА-РИТМА)}

\section{Изложение}

Введение: Целью настоящей работы являлась проверка связи между спонтанной электрической активностью мозга, показанной с помощью техники ЭЭГ для частоты 8-13 Гц (т.н. ритм Бергера) и активацией таламуса. Наиболее распространенная теория, относящаяся к генерации ритма Бергера, предполагает его источник в затылочно-таламической петли, но в литературе существуют большие разногласия относительно роли таламуса в этом процессе.

Материал и методы: В исследованиях использован сканер Siemens Magnetom Trio с индукционным поле 3Т и 64-канальная система SynAmps2 фирмы Neuroscan. В исследовании взяло участие 36 здоровых молодых мужчин. Исследовательская схема состояла из чередующихся блоков, при которых исследуемый человек должен был иметь закрытые или открытые глаза (всего 12 блоков). Обработка данных ЭЭГ включала в себя следующие шаги: 1) удаление артефакта, вызванного действием градиентных каналов в результате исследования фМРТ, 2) редукция артефакта BCG, 3) полосно-пропускная фильтрация для частот 1-20 Гц. Сегменты, включающие альфа-ритм были обозначены на данных после фильтрации. Данные фМРТ были обработаны согласно общепринятой процедуре (коррекция движения, нормализация, выглаживание). Анализ с использованием основной линейной модели (анг. generallinear model - GLM) был произведен на основании сегментов альфа-ритма, полученных из записи ЭЭГ. При моделировании была использована функция гемодинамического ответа, приспособленного к физиологии таламуса.

Результаты: На основании данных ЭЭГ была получена типическая пространственная дистрибуция альфа-ритма, с наивысшей амплитудой, наблюдаемой в теменно-затылочныхэлектродах. Групповой анализ данных фМРТ не показал никакой существенной активности в области таламуса. Однако подробная верификация данных позволила определить три подгруппы: 1) со сниженным сигналом в вентромедиальном ядре с левой стороны, 2) с повышеным сигналом в области отдельных структур таламуса, 3) без заметных изменений сигнала в таламусе.

Итоги: На основании полученных результатов можно сделать вывод, что таламус может быть по-разному задействован в генерации альфа-ритма. Почвой наблюдаемой меж-индивидуальной вариабельности могут быть физиологические механизмы, связанные с ритмом Бергера.

\section{WERYFIKACJA ZMIENNOŚCI MIĘDZYOSOBNICZEJ AKTYWNOŚCI WZGÓRZA PODCZAS GENERACJI RYTMU BERGERA (RYTMU ALFA)}

\section{Streszczenie}

Wprowadzenie: Celem niniejszej pracy było sprawdzenie związku między spontaniczną aktywnością elektryczną mózgu uwidocznioną techniką EEG dla częstotliwości 8-13 Hz (tzw. rytm Bergera) a aktywacją wzgórza. Najbardziej rozpowszechniona teoria dotycząca generacji rytmu Bergera sugeruje jego źródło w pętli wzgórzowo-potylicznej, ale w piśmiennictwie występują duże rozbieżności co do roli wzgórza w tym procesie.

Materiał i metody: Do badań wykorzystano skaner Siemens Magnetom Trio o polu indukcji 3T oraz 64-kanałowy system SynAmps2 firmy Neuroscan. W badaniu uczestniczyło 36 zdrowych młodych mężczyzn. Schemat badawczy składał się z naprzemiennych bloków, gdzie osoba badana miała mieć zamknięte bądź otwarte oczy (łącznie 12 bloków). Przetwarzanie danych EEG obejmowało kroki: 1) usunięcie artefaktu wywołanego działaniem cewek gradientowych w wyniku badania fMRI, 2) redukcja artefaktu BCG, 3) filtracja pasmowo-przepustowa dla częstotliwości 1-20 Hz. Segmenty obejmujące rytm alfa zostały oznaczone na danych po filtracji. Dane fMRI zostały przetworzone zgodnie z powszechnie przyjętą procedurą (korekcja ruchu, normalizacja, wygładzenie). Analiza z wykorzystaniem generalnego modelu liniowego (ang. 
general linear model - GLM) została wykonana na podstawie segmentów rytmu alfa otrzymanych z zapisu EEG. Przy modelowaniu zastosowano funkcję odpowiedzi hemodynamicznej dopasowaną do fizjologii wzgórza.

Wyniki: W oparciu o dane EEG uzyskano typową dystrybucję przestrzenną rytmu alfa, z najwyższą amplitudą obserwowaną w elektrodach ciemieniowo-potylicznych. Analiza grupowa danych fMRI nie wykazała żadnej istotnej aktywności w obrębie wzgórza. Jednakże szczegółowa weryfikacja danych pozwoliła określić trzy podgrupy: 1) z obniżonym sygnałem w jądrze brzuszno-przyśrodkowym po lewej stronie, 2) z podwyższonym sygnałem w obrębie poszczególnych struktur wzgórza, 3) bez zauważalnych zmian sygnału we wzgórzu.

Wnioski: Na podstawie uzyskanych wyników można zauważyć, że wzgórze może być w różny sposób zaangażowane w generację rytmu alfa. Podłożem obserwowanej zmienności międzyosobniczej mogą być mechanizmy fizjologiczne związane z rytmem Bergera.

\section{Background}

Berger's rhythm is a posterior alpha rhythm $(8-13 \mathrm{~Hz})$, generated when a person is awake with eyes closed and suppressed by opening the eyes, sleep, or mental effort $[1,2]$ (see paragraph 3 of the Discussion for definition of terms). The phenomenon has been extensively studied in animals and humans [3-10]. Previous studies using quantitative EEG signal analysis have shown abnormalities in the posterior alpha rhythm in many neurological and neurodevelopmental disorders, such as Alzheimer's disease [11], mild cognitive impairment [12], migraine [13], autism spectrum disorders [14], and dyslexia [15]. The alpha rhythm has also been recognized as the dominant brain activity in coma [2]. Despite its clinical relevance, however, the functions of the alpha rhythm have not been fully recognized. For many years neural activity in the alpha range has been thought to represent an idling process in the visual system [16]. In support of this, many EEG studies have found a decrease in alpha power over occipital sites during visual stimulation $[1,17]$. More recently, decreased power in posterior alpha oscillations has been considered to represent increased attention [18]. At the same time, an increase of alpha rhythm amplitude is believed to reflect general inhibitory mechanisms [19].

The brain source of the alpha rhythm is still not clear [20]. Early animal studies have shown that the alpha rhythm is generated by reciprocal circuits between thalamic and cortical regions $[6,9]$. Other animal trials have indicated the occipital cortex and the visual thalamus (lateral geniculate bodies and pulvinar) as the principal generators of alpha oscillations $[3,4,10]$. The thalamus is, however, difficult to assess non-invasively with EEG alone due to the very low sensitivity of the technique to signal generators located in subcortical brain structures.

Recently, simultaneous recording of the EEG and the fMRI signals has been applied to examine the alpha rhythm and its neuronal correlates in humans. Nevertheless, recent studies have not provided conclusive results on the generation of Berger's alpha rhythm, especially concerning the thalamus. The first study to use this neuroimaging technique showed an increased alpha power accompanied with increased responses in the thalamus, among other cortical activations [21]. Further research, however, has provided varied results on the direction of correlation (positive, negative, or none) between the posterior alpha rhythm in EEG and the BOLD signal in the thalamus [22-31]. One possible cause of these discrepancies might be the simplified assumption of a standard hemodynamic response function (HRF), with minimal variability across brain regions. A number of studies have shown that this assumption is often violated and the shape of the HRF might differ in various brain regions within the same subject [28]. The general purpose of this study was to verify involvement of the thalamus in the generation of Berger's rhythm using simultaneous EEG-fMRI registration. In order to overcome the described limitations, a modified hemodynamic response function has been used to model thalamic responses [28].

\section{Material and Methods}

\section{Subjects}

Thirty-six young male adults (mean age $=26$ years 8 months \pm 3 years 11 months) were recruited for the study. This specific population was selected to limit the effect of factors such as gender and age on thalamic activation during Berger's alpha rhythm generation [32]. Participants had no history of neuropsychiatric disorders or head injury. Subjects provided written informed consent to participate in the trial. The project was approved by the Ethics Committee of the Institute of Physiology and Pathology of Hearing and conformed to the Declaration of Helsinki for Medical Research Involving Human Subjects.

\section{Experimental design}

Prior to EEG-fMRI registration all subjects were familiarized with the MR scanner environment in order to make them feel comfortable and relaxed during the experiment. NordicNeuroLab goggles and headphones were used for visual and auditory stimulation. An EEG study procedure aimed at eliciting Berger's effect was adapted to fMRI requirements. Subjects were instructed to rest wakefully while alternately keeping eyes closed or open (30 s for each block). They were presented with a grey screen with a black cross in the middle ('eyes open' block) and were asked to close their eyes when the screen changed to black ('eyes closed' block). A sound (500 ms pure tone of 500 $\mathrm{Hz}$ at $80 \mathrm{~dB}$ SPL) indicated that the subjects should open their eyes again. The whole procedure was repeated 6 times and involved 12 blocks (6 minutes in total).

\section{EEG recording}

EEG recordings were obtained using the Neuroscan SynAmps2 system with a 64-electrode (10/10 system) Maglink 

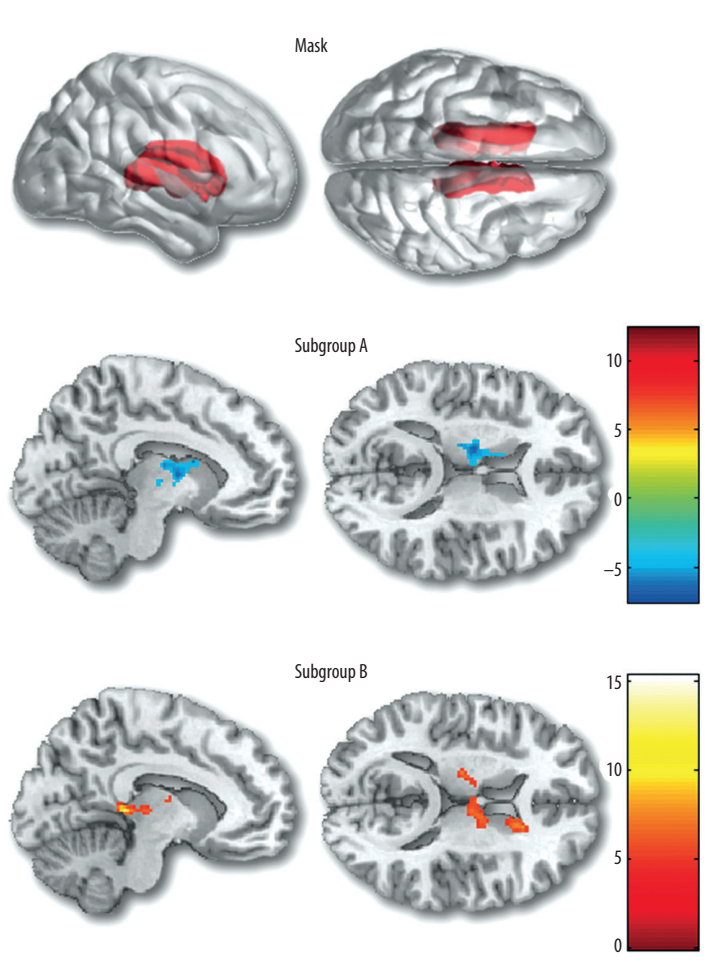

Figure 1. The fMRI results for two subgroups ( $A$ - negative; and $\mathrm{B}$ - positive correlations) using thalamus adjusted HRF (alpha vs. eyes closed t-contrast, $p<0.001$, cluster size $>126$ ). The mask encompassing thalamus and caudate nucleus (shown in the top of the figure) was used for computations

cap. The impedance of the skin-to-sintered $\mathrm{Ag} / \mathrm{AgCl}$ electrodes was kept below $15 \mathrm{k} \Omega$ for all electrodes. The signal was registered continuously at a $10 \mathrm{kHz}$ sampling rate. Clock synchronization between the MR scanner hardware and the EEG system was assured by a NeuroScan MRI/ EEG clock synchronization unit.

\section{fMRI image acquisition}

FMRI data were acquired continuously during EEG recording in a 3T scanner (Siemens Magnetom Trio TIM). A standard 12-channel matrix head coil was used for RF signal reception. fMRI data were obtained using a $\mathrm{T}^{*}$ weighted gradient echo-planar imaging (EPI) sequence (TR $3000 \mathrm{~ms}$, TE $30 \mathrm{~ms}$, FA $90^{\circ}$, image matrix $96 \times 96$, plane FOV $192 \times 192 \mathrm{~mm}$, iPAT=2) with 42 ascending slices (slice thickness $3 \mathrm{~mm}$, no gap) parallel to the axial plane. There were 120 volumes (plus 3 extra dummy scans for steady-state magnetization) collected in the total scanning time of $6 \min 11 \mathrm{~s}$.

\section{EEG signal analysis}

First, electric artifacts induced by the MRI scanner gradient coils were removed from the EEG signal using average artifact subtraction (Compumedics SCAN 4.5 software) [33]. Balistocardiogram (BCG) artifacts were then removed from the EEG signal. We used a correlation-based

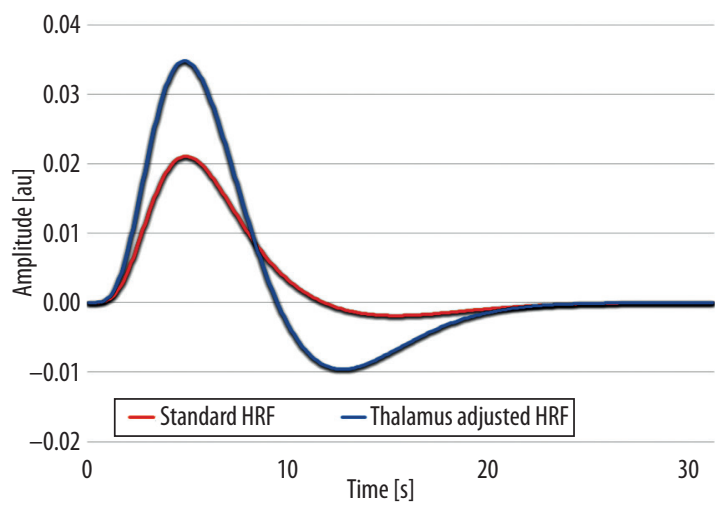

Figure 2. Canonical HRF function (red) and HRF function adjusted to thalamus specificity (blue) as suggested by de Munck et al. [28]

algorithm implemented in BESA 6 software to find most of the R peaks of the QRS complex detected at the ECG electrode. The artifact filtration method was the same as in our previous work [34]. Finally, the EEG signal was filtered using a band-pass filter (finite impulse response [FIR] with zero phase shift, cut-off frequencies of 1-20 Hz, $12 \mathrm{~dB} /$ oct slope) and re-referenced to a common reference. In addition, the data was resampled at $100 \mathrm{~Hz}$. Alpha bursts were detected using a cross-correlation approach, with correlation coefficients between the EEG signal and the predefined alpha-burst template calculated for each subject and each electrode independently.

\section{fMRI signal analysis}

The fMRI signal analysis was performed using statistical parametric mapping software (SPM8, Wellcome Trust Centre for Neuroimaging, London, UK) in a MATLAB environment. The data were slice-time corrected, realigned, normalized to a common brain space (Montreal Neurological Institute template using ICBM152 EPI image), and spatially smoothed with an 8-mm FWHM Gaussian kernel. A GLM was created using a block-design paradigm. The model was extended with event-related responses using alpha bursts obtained from the EEG signal as events. Alpha bursts were modeled with a stimulus duration equal to 0 (stick-function) [35] and convolved with a double-gamma function (hemodynamic response function, HRF) to obtain the final regressor. To investigate subcortical (thalamus) activations, a trimmed HRF function was used as proposed by de Munck et al. [28]. We used a common inclusive mask for thalamic and caudate structures (as shown in the top of Figure 1). Cortical structures were masked out because a HRF adjusted to BOLD signal parameters of the thalamus has been shown unsuitable to assess cortical response patterns $[28,36]$. The delay of the HRF undershoot was shifted from $16 \mathrm{~s}$ to $13 \mathrm{~s}$ and the ratio of response to undershoot was changed from 6 : 1 to 2: 1 . The modified HRF is compared with the standard HRF in Figure 2. 


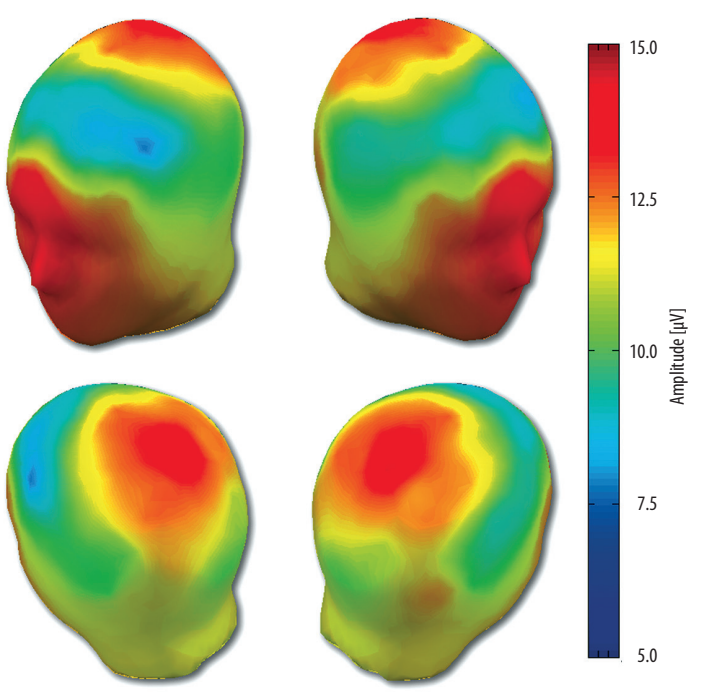

Figure 3. The scalp distribution of the average amplitude in alpha band across subjects. The map was obtained using Fast Fourier Transformation in $180 \mathrm{~s}$ window (i.e. all eyes closed blocks)

\section{Results}

The eyes closed-related alpha rhythm associated with Berger's effect had a typical scalp distribution with the highest amplitudes detected in the occipital cortex and the frontal pole (Figure 3). Whole-group fMRI analysis revealed no significant activation in the thalamus $(n=36)$. However, three patterns of thalamic activity were distinguished across individuals: (a) a negative correlation between alpha bursting activity and BOLD signal in the left medial dorsal nucleus (subgroup A, $n=9$ ); (b) positive BOLD-alpha burst correlation in the right medial dorsal nucleus, right caudate body, and pulvinar (subgroup $\mathrm{B}, n=8$ ); and (c) no correlation between alpha bursting activity and BOLD signal in the thalamus $(n=19)$. Statistically significant outcomes in subgroup A and subgroup B $(p<0.001)$, as well as the subcortical mask, are presented in Figure 1.

\section{Discussion}

In the present EEG-fMRI study we found diverse patterns of correlations of thalamic activation with the alpha bursting activity (associated with Berger's effect). The EEG data confirmed the usual scalp distribution of the alpha rhythm, manifesting mainly in posterior areas of the brain. At the same time, we showed that the thalamus is not necessarily involved in the generation of the alpha rhythm, contradicting the leading theory on the source of the Berger's effect-related alpha rhythm activity [6,9]. Using GLM modeling with a trimmed thalamus-adjusted HRF, we showed thalamic activity in the medial dorsal nuclei in only about half of the subjects, and in those cases they had different directions of correlation between the alpha rhythm and the registered BOLD signal (Figure 1). The other half of participants had no thalamic responses at all. This indicates that the neuronal sources of Berger's alpha rhythm might actually be only cortical, an assumption which requires further investigation.
Previous neuroimaging studies [22-31] have generally been consistent in terms of correlation of Berger's alpha rhythm with response patterns in cortical regions (the thalamo-occipital circuit [5]), but not in the thalamus. At the same time, electrophysiological evidence from isolated cerebral cortex cells in dogs found that cortical circuits were capable of generating alpha waves independent of the thalamus [5,37], with human studies showing the occipital alpha rhythm still present after bilateral lesions in the thalamus [38]. Furthermore, other animal trials have indicated that the alpha rhythm might actually be aligned with a more distributed brain network beyond the extensively described thalamo-occipital circuit $[7,8]$.

A considerable inconsistency in naming of the alpha rhythm renders the interpretation of results obtained across different labs challenging [39]. The term 'alpha rhythm' refers mainly to the posterior cerebral activity but can also indicate alpha band oscillations in other regions of the brain. Some researchers use other terms for the rhythmic neuronal activation during eyes closed which is suppressed by eyes opening, i.e. Berger's effect, such as 'alpha waves' and 'alpha band' [26]. Furthermore, there is a large number of papers exploring the alpha rhythm during resting state experiments without Berger's effect verification [23,40], which leads to divergent interpretations of the psycho-physiological role of the alpha activity [19]. Lately, Ben-Simon et al. [40] have shown two different brain networks involved in the generation of spontaneous and induced oscillatory (Berger's effect-related) alpha rhythm. The first mechanism can be related to the inhibitory role of the alpha rhythm with thalamus as the major generator, whereas elicited alpha activity could reflect the resting state in which thalamic activity is not essential (as it is expected in some recent works $[41,42]$ ). The latter could explain the relatively high variability among participants of the current study, in terms of the involvement of the thalamus.

There are certain limitations to our study. We cannot exclude that the findings of the current trial might be related to a still insufficient model of thalamic hemodynamic activity. It is possible that differences in the direction of the alpha bursting activity and the thalamus correlation (positive or negative), shown by many authors and also in our study, result from intersubject variability in the hemodynamic response function [43]. It seems that even a minor shift in the GLM, relative to the real data, can change the results from a positive to a negative correlation or even produce statistically insignificant differences. This is due to the fact that the undershoot of the HRF of the thalamus is larger than in the canonical (cortical) HRF that can be seen in Figure 2. At the same time, however, the significant advantage of our study is a relatively large $(n=36)$ and homogenous (young males) group of participants. Since previous studies have demonstrated gender and age differences in the alpha rhythm [32], we aimed to exclude these potential confounding effects. Moreover, most authors report corresponding EEG-fMRI results obtained in fewer participants $(n<15)$ than in our study (e.g. $[23,40])$, which we claim is not particularly suitable for examining the variability of the results in detail (27]. 


\section{Conclusions}

On the basis of the existing literature and our own EEGfMRI results, we can conclude that the thalamus might be differently involved in the alpha rhythm generation and not critically important in this process. Hence, the observed intersubject variability might be caused by different physiological mechanisms underlying Berger's rhythm.

\section{Acknowledgments}

This study was supported by NSC grant no.2011/01/N/ NZ4/04985.

\section{References:}

1. Berger PDH. Über das Elektrenkephalogramm des Menschen. Arch Für Psychiatr Nervenkrankh, 1929; 87: 527-70.

2. Niedermeyer E. The normal EEG of the waking adult.: 149-73.

3. Da Silva FH, van Lierop TH, Schrijer CF, van Leeuwen WS. Organization of thalamic and cortical alpha rhythms: spectra and coherences. Electroencephalogr Clin Neurophysiol, 1973; 35: 627-39.

4. Lopes Da Silva FH, Storm Van Leeuwen W. The cortical source of the alpha rhythm. Neurosci Lett, 1977; 6: 237-41.

5. Lopes Da Silva FH, Vos JE, Mooibroek J, Van Rotterdam A. Relative contributions of intracortical and thalamo-cortical processes in the generation of alpha rhythms, revealed by partial coherence analysis. Electroencephalogr Clin Neurophysiol, 1980; 50: 449-56.

6. Andersen P, Andersson SA. Physiological basis of the alpha rhythm. Appleton-Century-Crofts; 1968.

7. Başar E, Schürmann M, Başar-Eroglu C, Karakaş S. Alpha oscillations in brain functioning: an integrative theory. Int J Psychophysiol, 1997; 26: 5-29.

8. Schürmann M, Başar E. Functional aspects of alpha oscillations in the EEG. Int J Psychophysiol, 2001; 39: 151-8.

9. Bishop GH. The interpretation of cortical potentials. Cold Spring Harb Symp Quant Biol, 1936; 4: 305-19.

10. Moruzzi G, Magoun HW. Brain stem reticular formation and activation of the EEG. Electroencephalogr Clin Neurophysiol, 1949; 1: 455-73.

11. Prinz PN, Vitiell MV. Dominant occipital (alpha) rhythm frequency in early stage Alzheimer's disease and depression. Electroencephalogr Clin Neurophysiol, 1989; 73: 427-32.

12. Luckhaus C, Grass-Kapanke B, Blaeser I et al. Quantitative EEG in progressing vs. stable mild cognitive impairment (MCI): results of a 1-year follow-up study. Int J Geriatr Psychiatry, 2008; 23: $1148-55$.

13. Bjørk MH, Stovner LJ, Nilsen BM, Stjern M, Hagen K, Sand T. The occipital alpha rhythm related to the "migraine cycle" and headache burden: a blinded, controlled longitudinal study. Clin Neurophysiol, 2009; 120: 464-71.

14. Mathewson KJ, Jetha MK, Drmic IE, Bryson SE, Goldberg JO, Schmidt LA. Regional EEG alpha power, coherence, and behavioral symptomatology in autism spectrum disorder. Clin. Neurophysiol, 2012; 123: 1798-809.

15. Babiloni C, Stella G, Buffo P, Vecchio F, Onorati P, Muratori $\mathrm{C}$ et al. Cortical sources of resting state EEG rhythms are abnormal in dyslexic children. Clin Neurophysiol, 2012; 123: 2384-91.

16. Cooper NR, Croft RJ, Dominey SJJ, Burgess AP, Gruzelier JH. Paradox lost? Exploring the role of alpha oscillations during externally vs. internally directed attention and the implications for idling and inhibition hypotheses. Int J Psychophysiol, 2003; 47: 65-74.
17. Pfurtscheller G, Stancak Jr A, Neuper C. Event-related synchronization (ERS) in the alpha band - an electrophysiological correlate of cortical idling: a review. Int J Psychophysiol, 1996; 24: 39-46.

18. Thut G. Alpha-band electroencephalographic activity over occipital cortex indexes visuospatial attention bias and predicts visual target detection. J Neurosci, 2006; 26: 9494-502.

19. Klimesch W, Sauseng P, Hanslmayr S. EEG alpha oscillations: the inhibition-timing hypothesis. Brain Res Rev, 2007; 53: 63-88.

20. Laufs H. A personalized history of EEG-fMRI integration. Neuroimage, 2012; 62: 1056-67.

21. Goldman RI, Stern JM, Engel J, Cohen MS. Simultaneous EEG and fMRI of the alpha rhythm. Neuroreport. 2002; 13: 2487-92.

22. Danos P, Guich S, Abel L, Buchsbaum MS. EEG alpha rhythm and glucose metabolic rate in the thalamus in schizophrenia. Neuropsychobiology, 2001; 43: 265-72.

23. Laufs H, Kleinschmidt A, Beyerle A, Eger E, Salek-Haddadi A, Preibisch $\mathrm{C}$ et al. EEG-correlated $\mathrm{fMRI}$ of human alpha activity. Neuroimage, 2003; 19: 1463-76.

24. Laufs H, Holt JL, Elfont R, Krams M, Paul JS, Krakow K et al. Where the BOLD signal goes when alpha EEG leaves. Neuroimage, 2006; 31: 1408-18.

25. Moosmann M, Eichele T, Nordby H, Hugdahl K, Calhoun VD. Joint independent component analysis for simultaneous EEGfMRI: principle and simulation. Int J Psychophysiol, 2008; 67: 212-21.

26. Feige B, Scheffler K, Esposito F, Salle FD, Hennig J, Seifritz E. Cortical and subcortical correlates of electroencephalographic alpha rhythm modulation. J Neurophysiol, 2005; 93: 2864-72.

27. Gonçalves SI, de Munck JC, Pouwels PJ, Schoonhoven R, Kuijer JP, Maurits NM et al. Correlating the alpha rhythm to BOLD using simultaneous EEG/fMRI: inter-subject variability. Neuroimage, 2006; 30: 203-13.

28. de Munck JC, Gonçalves SI, Huijboom L, Kuijer JP, Pouwels PJ, Heethaar RM et al. The hemodynamic response of the alpha rhythm: an EEG/fMRI study. Neuroimage, 2007; 35: 1142-51.

29. Laufs H. Endogenous brain oscillations and related networks detected by surface EEG-combined fMRI. Hum Brain Mapp, 2008; 29: 762-9.

30. Sadaghiani S, Scheeringa R, Lehongre K, Morillon B, Giraud A-L, Kleinschmidt A. Intrinsic connectivity networks, alpha oscillations, and tonic alertness: a simultaneous electroencephalography/functional magnetic resonance imaging study. J Neurosci, 2010; 30: 10243-50.

31. Liu Z, de Zwart JA, Yao B, van Gelderen P, Kuo L-W, Duyn JH. Finding thalamic BOLD correlates to posterior alpha EEG. Neuroimage, 2012; 63: 1060-9.

32. Chiang AKI, Rennie CJ, Robinson PA, van Albada SJ, Kerr CC. Age trends and sex differences of alpha rhythms including split alpha peaks. Clin Neurophysiol, 2011; 122: 1505-17. 
33. Allen PJ, Josephs O, Turner R. A Method for removing imaging artifact from continuous EEG recorded during functional MRI. Neuroimage, 2000; 12: 230-9.

34. Rusiniak M, Lewandowska M, Wolak T, Pluta A, Milner R, Ganc $\mathrm{M}$ et al. A modified oddball paradigm for investigation of neural correlates of attention: a simultaneous ERP-fMRI study. Magn Reson Mater Phys Biol Med, 2013; 26: 511-26.

35. Friston KJ, editor. Statistical parametric mapping: the analysis of funtional brain images. $1^{\text {st }}$ ed. Amsterdam ; Boston: Elsevier/Academic Press; 2007.

36. Glover GH. Deconvolution of impulse response in event-related BOLD fMRI. Neuroimage, 1999; 9: 416-29.

37. Kristiansen K, Courtois G. Rhythmic electrical activity from isolated cerebral cortex. Electroencephalogr. Clin Neurophysiol, 1949; 1: 265-72.
38. Yazawa S, Kawasaki S, Kanemaru A, Kuratsuwa Y, Yabuoshi R, Ohi T. Bilateral paramedian thalamo-midbrain infarction showing electroencephalographic alpha activity. Intern Med Tokyo Jpn, 2001; 40: 443-8.

39. Bazanova OM, Vernon D. Interpreting EEG alpha activity. Neurosci Biobehav Rev, 2014; 44: 94-110.

40. Ben-Simon E, Podlipsky I, Arieli A, Zhdanov A, Hendler T. Never resting brain: simultaneous representation of two alpha related processes in humans. PLoS One, 2008; 3: e3984

41. Zhan Z, Xu L, Zuo T, Xie D, Zhang J, Yao L et al. The contribution of different frequency bands of fMRI data to the correlation with EEG alpha rhythm. Brain Res, 2014; 1543: 235-43.

42. Mo J, Liu Y, Huang H, Ding M. Coupling between visual alpha oscillations and default mode activity. Neuroimage, 2013; 68: $112-8$.

43. de Munck JC, Gonçalves SI, Huijboom L, Kuijer JP, Pouwels PJ, Heethaar RM et al. The hemodynamic response of the alpha rhythm: An EEG/fMRI study. Neuroimage, 2007; 35: 1142-51. 